\title{
Penerapan Metode Diskusi dalam Peningkatan Minat Belajar
}

\author{
${ }^{1}$ Irwan , ${ }^{2}$ Hasbi, ${ }^{3}$ Rosdiana \\ ${ }_{1}^{1}$ Program Studi Pendidikan Agama Islam, FTIK, IAIN Palopo \\ E-mail: irwan731@gmail.com
}

\begin{abstract}
This research is a classroom action research (CAR) which aims to determine the increasing interest in learning through discussion methods. Subjects in the study were students of class $X-7$ as many as 24 students (11 sons and 13 daughters) SMA 4 Kota Palopo. The results showed that: the application of the discussion method was carried out in 3 stages: a). The stage before a meeting. b). The stage during the meeting and c) Stage after the meeting. Then before the researcher conducts research in class. Researchers first take student data to the teacher in the field of Islamic Education as a comparison of the results of pre-cycle learning, the cycle I and cycle II. The average value of students in class X-7 before applying the discussion method is only $47.08 \%$, which means that it is still below the limit of students' completeness. In the first cycle, researchers have applied the discussion method to the average value of students reaching $69.5 \%$. In cycle II the average value of students reached $84.16 \%$. This has proven that the application of the discussion method can improve students' learning interest in the subjects of Islamic Religion in the X-7 class of SMA 4 Palopo.
\end{abstract}

Keywords: Method of discussion, student learning interest

\begin{abstract}
Abstrak
Penelitian ini adalah penelitian tindakan kelas (PTK) yang bertujuan untuk mengetahui peningkatan minat belajar melalui metode diskusi. Subjek dalam penelitian adalah siswa kelas X-7 sebanyak 24 siswa (11 putra dan 13 putri) SMA Negeri 4 Kota Palopo. Hasil penelitian menunjukkan bahwa: penerapan metode diskusi dilaksanakan dalam 3 tahapan yaitu a). Tahap sebelum pertemuan. b). Tahap selama pertemuan dan c) Tahap setelah pertemuan. Kemudian sebelum peneliti melaksanakan penelitian di kelas. Peneliti terlebih dahulu mengambil data siswa kepada guru bidang studi Pendidikan Agama Islam sebagai perbandingan hasil nilai belajar prasiklus, siklus I dan siklus II. Nilai rata-rata siswa kelas X-7 sebelum diterapkan metode diskusi hanya 47,08\% ini berarti masih di bawah batas ketuntasan siswa. Pada siklus I peneliti telah menerapkan metode diskusi nilai rata-rata siswa mencapai 69,5\%. Pada siklus II nilai rata-rata siswa mencapai 84,16\%. Hal ini telah membuktikan bahwa dengan penerapan metode diskusi dapat meningkatkan minat belajar siswa pada mata pelajaran Pendidikan Agama Islam di kelas X-7 SMA Negeri 4 Palopo.
\end{abstract}

Kata Kunci: Metode diskusi, minat belajar siswa 


\section{Pendahuluan}

Sekolah sebagai lembaga formal merupakan salah satu wadah untuk mewujudkan tujuan tersebut melalui kegiatan pembelajaran. Sekarang ini berbagai pendekatan maupun metode mengajar banyak digunakan agar tujuan dari proses pembelajaran dapat tercapai. Tapi, sampai saat ini pendidikan di Indonesia masih didominasi oleh kelas yang berfokus pada guru sebagai pusat pengetahuan, sehingga ceramah akan menjadi pilihan utama dalam menentukan strategi belajar. Padahal belajar adalah suatu proses usaha yang dilakukan oleh individu untuk memperoleh suatu perubahan tingkah laku secara keseluruhan sebagi hasil pengalaman dalam interaksi dengan lingkungannya. ${ }^{1}$

Bedasarkan pengamatan peneliti selama PPL di SMA Negeri 4 Palopo menjumpai adanya beberapa permasalahan, diantaranya adalah kurangnya guru menggunakan pendekatan dan metode yang tepat sehingga siswa kurang aktif dan kurang bergairah dalam mengikuti pembelajaran di kelas sehingga minat belajar belum maksimal. Khususnya di kelas X.7 guru lebih dominan menggunakan metode ceramah sehingga tidak adanya interaksi antara pendidik dengan siswa. Akibatnya, banyak siswa yang nilainya dibawah standar kriteria ketuntasan minimal (KKM) sehingga minat belajar siswa menjadi rendah. Hal tersebut yang menjadikan alasan peneliti menggunakan metode diskusi dalam pembelajaran Pendidikan Agama Islam

\section{Kerangka Teoretis}

\section{Minat Belajar}

Minat adalah kecenderungan hati yang tinggi terhadap sesuatu. Minat belajar berarti kecenderungan hati terhadap mata pelajaran, sehinga muncullah kondisi yang bernuansa iqra' (baca) dan selalu rindu terhadap mata pelajaran, sehingga tercipta kondisi dimanapun dan kapanpun akan rindu terhadap mata pelajaran sehingga dapar dikatakan (long life education). ${ }^{2}$ Jika minat telah memenuhi jiwa siswa, maka akan semakin mudah bagi guru untuk mengarahkannya kepada mata pelajaran tetentu.

${ }^{1}$ Ahmadi, Psikologi Belajar, (Jakarta: Rineka Cipta, 2004), h.128.

2Departemen Pendidikan dan Kebudayaan, Kamus Besar Bahasa Indonesia, ( Cet. III; Jakarta: Balai Pustaka, 1994), h. 24. 
Minat adalah dorongan atau aktivitas mental yang dapat merangsang perasaan senang terhadap sesuatu. ${ }^{3}$ Sesuatu itu bisa berupa orang, benda, kegiatan, pengalaman, dan lain-lain yang dapat dijadikan sebagai stimulus yang memerlukan respons terarah. minat juga berarti suatu rasa lebih suka keterikatan pada suatu hal atau aktivitas tanpa ada yang menyuruh. ${ }^{4}$ Semakin dekat individu dengan apa yang ada di luar dariya, maka minat semakin bertambah. Minat dapat termanifestasi melalui partisipasi dalam suatu aktivitas. Minat tidak dibawah sejak lahir melainkan diperoleh melalui belajar, dengan belajar maka minat baru akan terbentuk dan akan menjadi penyanggah untuk belajar selanjutnya.

Minat tidak dapat dipisahkan dengan kebiasaan karena dua hal tersebut berbeda tetapi berkaitan, yaitu perpaduan antara keinginan dan kemauan yang dapat berkembang jika motivasi sebagai penggerak dalam melakukannya. Pengembangan minat terhadap sesuatu sangat membantu siswa, ini terlihat bagaimana hubungan antara materi yang diharapkan untuk dipelajarinya dengan dirinya sendiri sebagai individu. Proses ini menunjukkan pada siswa bagaimana pengetahuan atau kecakapan tertentu mempengaruhi dirinya.

Minat merupakan salah satu fungsi hidup kewajiban manusia, dapat diartikan sebagai aktivitas psikis yang mengandung usaha aktif dan berhubungan dengan pelaksanaan suatu tujuan. Beberapa ahli pendidikan berpendapat bahwa cara lain yang efektif untuk membangkitkan minat pada siswa yang baru adalah dengan menggunakan minat siswa yang sudah ada. Misalnya siswa menaruh minat pada olahraga sepak bola, maka sebelum mengajar guru perlu menceritakan pertandingan atau tokoh-tokoh sepak bola yang populer kemudian diarahkan pada materi pelajaran yang sesungguhnya.

Ada empat hal yang perlu dilakukan oleh guru dalam rangka membangkitkan minat belajar siswa, yaitu:

1) Membangkitkan dorongan kepada siswa untuk belajar

2) Menjelaskan secara konkret kepada siswa apa yang dapat dilakukan pada akhir pengajaran

3 Zainal Arifin, op.cit., h. 241.

${ }^{4}$ Slameto, Belajar dan Faktor-faktor yang Mempengaruhinya, (Cet: IV Jakarta: PT. Rineka Cipta, 2003), h. 2. 
3) Memberikan ganjaran terhadap prestasi yang dicapai sehingga dapat merangsang untuk mendapat prestasi yang lebih baik dikemudian hari

4) Menggunakan metode mengajar yang bervariasi. $^{5}$

\section{Metode Diskusi}

Metode diskusi adalah sala satu cara mendidik yang berupaya memecahkan masalah yang di hadapai, baik dua orang atau lebih yang masingmasing mengajukan argumentasinya untuk memperkuat pendapatnya. ${ }^{6}$

Metode diskusi adalah cara penyajian pelajaran dimana peseta didik dihadapkan pada suatu masalah yang bisa berupa pernyataan atau pertanyaan yang bersifat problematik untuk dibahas dan dipecahkan bersama.

Dari uraian di atas dapat disimpulkan bahwa metode diskusi adalah suatu kegiatan belajar mengajar dalam bentuk tukar pendapat dari pertanyaan-pertanyaan yang ada, baik dari siswa secara individual atau secara kelompok maupun dari guru sehingga diperoleh suatu kesepakatan bersama dari permasalahan yang dikaji. Penggunaan metode diskusi kelas bertujuan untuk memberikan kesempatan kepada siswa untuk menyatakan pandangan mengenai apa yang menarik perhatian siswa. Guru dalam proses ini dapat mengetahui kepribadian dan cirri-ciri kognitif, afektif dan psikomotorik siswa.

Metode diskusi dapat digunakan dalam pengajaran Pendidikan Agama Islam utamanya pokok pembahasan tentang Sejarah Kebudayaan Islam. Metode diskusi ini diikuti oleh semua siswa di dalam kelas dan dapat pula dibentuk dalam kelompok-kelompok yang lebih kecil, yang terpenting adalah siswa harus berpartisipasi di dalam setiap forum diskusi.

1. Jenis-jenis Metode Diskusi

a. Diskusi Kelompok

Diskusi kelompok adalah metode pembelajaran yang menggunakan cara dialog atau Tanya jawab antar sesama anggota tim (kelompok). Tujuannya

${ }^{5}$ Slameto, Ibid, h. 175-176.

6 Pupuh Faturrohman \& M. Sobry Sutikno, Strategi Belajar Mengajar, (Bandung, PT. Refika Aditama, 2010), h. 62 
adalah untuk memperoleh pengetahuan yang utuh dan komprehensif. Diharapkan dari dialog dan tanya jawab ini setiap anggota kelompok dapat saling tukar informasi sekaligus saling melengkapi pengetahuan yang diperoleh satu sama lain. ${ }^{7}$

b. Diskusi Panel

Dikusi panel adalah diskusi yang terdiri dari dua orang atau lebih yang berbicara. Ada pendengar sebagai kelompok yang diajar. ${ }^{8}$

c. Diskusi Simposium

Diskusi ini hampir sama dengan diskusi panel, hanya sifatnya lebih resmi (formal). Diskusi Simposium adalah ada beberapa orang ahli, minimal dua, diundang untuk memberikan pidato tentang sautu masalah tertentu yang disoroti dari beberapa aspek yang berbeda. ${ }^{9}$

d. Debat

Mula-mula dipilihkan suatu topik yang menarik dan baik untuk diperdebatkan. Setelah itu kelompok dibagi menjadi dua. Masing-masing mempunyai kemampuan yang sama. ${ }^{10}$

\section{Tujuan Penerapan Metode Diskusi}

Tujuan dari diaplikasikannya metode diskusi ke dalam proses belajar mengajar, adalah untuk:

a. Mendorong siswa untuk berpikir kritis

b. Mendorong siswa mengepresikan pendapat secara bebas.

c. Memotivasi siswa menyumbangkan buah pikirannya dalam memecahkan masalah bersama.

${ }^{7}$ Jasa Ungguh Muliawan, 45 Model Pembelajaran Spektakuler, (Cet. I Ar Ruzz Media, 2016), h. 193

${ }^{8}$ Sriyono dkk. Teknik Belajar Mengajar dalam CBSA, (Jakarta: PT. Rineka Cipta 1992), h. 109.

${ }^{9}$ Ibid., h .111

${ }^{10}$ Suyanto dan Asep Jihad, Menjadi Guru Profesional stragtegi Meningkatkan Kualifikasi dan Kualitas Guru di Era Global, (Erlangga Groub, 2013), h. 118 
d. Mengambil satu atau beberapa alternative jawaban dalam memecahkan masalah berdasarkan bertimbangan yang saksama. ${ }^{11}$

3. Kelebihan Metode Diskusi

a. Suasana kelas akan hidup karena siswa mengarahkan pikirannya kepada masalah yang sedang didiskusikan.

b. Menyadarkan siswa bahwa masalah dapat dipecahkan dengan berbagai cara

c. Membiasakan siswa untuk mendengarkan pendapat orang lain sekalipun berbeda pendapatnya.

d. Menaikkan prestasi kepribadian individu siswa seperti toleransi, demokratis, kritis, berfikir sistematis dan percaya diri

e. Kesimpulan-kesimpulan diskusi mudah dipahami siswa karena mereka terlibat dalam proses berfikir sebelum sampai pada kesimpulan. ${ }^{12}$

4. Kelemahan Metode Diskusi

a. Memungkinkan adanya siswa yang tidak ikut aktif dalam diskusi, karena bagi mereka diskusi merupakan kesempatan untuk melepaskan diri dari tanggung jawab dan pengawasan guru.

b. Peserta diskusi mendapat informasi yang terbatas

c. Forum diskusi dapat dikuasai oleh siswa yang pandai dan suka berbicara saja.

5. Prosedur Penerapan Metode Diskusi

a. Tahapan Sebelum Pertemuan

1) Pemilihan topik diskusi, yakni suatu kegiatan yang dimaksudkan untuk menentukan topik diskusi untuk melakukannya, guru dan siswa menggunakan tujuan yang ingin dicapai serta minat dan latar belakang siswa sebagai kriteria.

2) Membuat rancangan garis besar diskusi yang akan dilaksanakan (jika memungkinkan bagi guru).

11 Suyanto dan Asep Jihad, Ibid 
3) Menentukan jenis diskusi yang akan dilaksanakan.

4) Mengorganisasikan siswa dan formasi kelas sesuai dengan jenis diksusinya.

a. Tahapan Selama Pertemuan

1) Guru memberikan penjelasan tentang tujuan dari diskusi, topik diskusi dan kegiatan diskusi yang akan dilakukan.

2) Siswa dan guru melaksanakan kegiatan disksusi (sesuai jenis diskusi yang digunakan).

3) Pelaporan dan penyimpulan hasil diskusi oleh siswa bersama guru.

4) Pencatatan hasil diskusi oleh siswa.

b. Tahapan Setelah Pertemuan

Setelah melaksanakan tahapan sebelum dan selama pertemuan maka siswa di bombing untuk membuat catatan tentang gagasan-gagasan yang belum ditanggapi dan kesulitan yang timbul selama disksusi. Mengevaluasi disksusi dari berbagai dimensi dan mengumpulkan evaluasi dari para siswa serta lembaran komentar. ${ }^{13}$ Pada tahapan ini guru harus mampu menyimpulkan materi yang sedang dipelajari.

\section{Metode dan Hasil Penelitian}

Penelitian ini merupakan jenis penelitian tindakan kelas (PTK). Lokasi penelitian ini yaitu di SMA Negeri 4 Palopo. Dengan subjek penelitian siswa kelas X-7 yang tediri dari 24 siswa (11 putra dan 13 putri). Pelaksanaan penelitian mulai pada tanggal 14 November 2016 sampai 12 Desembar 2016 tahun pelajaran 2016/2017.

Adapun gambaran penelitian yang dilakukuan yaitu:

\section{a. Siklus I}

1) Perencanaan

13 Suyanto dan Asep Jihad, Ibid 
Perencanaan adalah persiapan yang dilakukan untuk pelaksanaan penelitian tindakan kelas. Pada tahap perencanaan ini peneliti melakukan persiapan-persiapan antara lain sebagai berikut:

(a) Membuat rencana pelaksanaan pembelajaran (RPP) tentang materi yang akan diajarkan dengan menggunakan metode diskusi. Materi yang akan diajarkan pada siklus satu yaitu memahami subtansi dan strategi dakwah Rasulullah Saw.

(b) Membuat soal test essay untuk mengetahui minat belajar siswa pada siklus I.

2) Pelaksanaan

Pelaksanaan merupakan implementasi dari semua rencana tindakan yang telah dibuat. Adapun langkah-langkah yang dilakukan adalah:

(a) Peneliti menyampaikan tujuan pembelajaran dan kegiatan yang akan dilaksanakan.

(b) Peneliti memberikan apersepsi tentang materi yang akan diajarkan.

(c) Peneliti membagi siswa menjadi 4 kelompok yang terdiri dari 6 siswa. Dimana, setiap kelompok diberikan sub materi yang berbeda.

(d) Peneliti memberikan kesempatan kepada setiap kelompok untuk mendiskusikan materi yang diberikannya kemudian menyampaikan hasil kerja kelompoknya.

(e) Setiap kelompok diberikan kesempatan untuk bertanya.

(f) Peneliti memberikan bimbingan kepada siswa selama berjalannya diskusi.

(g) Mengevaluasi proses dan hasil kegiatan diskusi.

3) Pengamatan

Pengamatan adalah kegiatan yang dilakukan bersamaan dengan pelaksanaan tindakan dengan melihat langsung kegiatan proses pembelajaran.

Berdasarkan pengamatan yang dilakukan selama proses pembelajaran berlangsung diperoleh hasil sebagai berikut: 
(a) Peserta didik sebagian besar menyukai metode diskusi.

(b) Dari 24 orang siswa tidak semuanya terlihat aktif dalam proses pembelajaran dengan menerapkan metode diskusi.

(c) Sebagian siswa masih memiliki sifat malu untuk bertanya.

(d) Keberanian peserta didik mengemukakan pendapat masih kurang.

(e) Hasil evaluasi mengenai peningkatan minat belajar siswa masih sedikit yang meningkat.

4). Refleksi

Refleksi merupakan tahapan untuk mengkaji dan memproses data yang didapat saat dilakukan pengamatan. Refleksi dilakukan untuk menentukan apakah siklus I harus diulangi atau sudah berhasil. Berdasarkan pengamatan peneliti selama proses pembelajaran Pendidikan Agama Islam berlangsung pada siklus I, pembelajaran dengan penerapan metode diskusi sudah berjalan sesuai dengan prosedur yang telah direncanakan. Namun, sebagian siswa masih kurang berpartisipasi dalam mengikuti pembelajaran dengan serius. Selain, itu siswa masih merasa enggan dan malu untuk mengajukan pertanyaan dan mengemukakan pendapat sendiri yang sehubungan dengan materi yang diajarkan. Pertanyaan dan mengemukakan pendapat hanya diajukan oleh sebagian kecil siswa pada siklus pertama berlangsung.

Berdasarkan pelaksanaan pada siklus I diperoleh pelaksanaan pembelajaran masi kurang efektif karena masih belum melakukan kegiatan pembelajaran sesuai dengan RPP, selain itu siswa masi malu untuk mengajukan pertanyaan dan mengemukakan pendapatnya.

\section{b. Siklus II}

1) Perencanaan

Pada tahap ini peneliti merumuskan berdasarkan perencanaan ulang siklus pertama, yaitu sebagai berikut: 
(a) Membuat rencana pelaksanaan pembelajaran (RPP) tentang materi yang akan diajarkan dengan menggunakan metode diskusi. Materi yang akan diajarkan pada siklus dua yaitu mendeskripsikan subtansi dan strategi dakwah Rasulullah Saw.

(b) Membuat soal test essay dan soal tanya jawab untuk mengetahui minat belajar siswa pada saat penerapan metode diskusi.

2) Pelaksanaan

Pada pelaksanaan siklus kedua penelitian dilaksanakan sesuai dengan apa yang direncanakan yang terdapat dalam perencanaan pembelajaran sebagai berikut:

(a) Peneliti memberikan arahan dan motivasi kepada siswa tentang pentingnya mempelajari Pendidikan Agama Islam.

(b) Peneliti membagi siswa menjadi 4 kelompok yang terdiri dari 6 siswa. Setiap kelompok diberikan sub materi yang berbeda dan teman kelompok yang berbeda dari kelompok siklus I.

(c) Peneliti memberikan kesempatan kepada setiap kelompok untuk mendiskusikan materi yang diberikannya kemudian menyampaikan hasil kerja kelompoknya.

(d) Peneliti mengarahkan kepada setiap kelompok agar mengemukakan pendapat dan pertanyaan terkait sub materi dari kelompok lain.

(e) Peneliti mengajak siswa untuk mendiskusikan setiap pertanyaan dari perwakilan setiap kelompok.

(f) Peneliti memberikan bimbingan kepada siswa selama berjalannya diskusi.

3) Pengamatan

Pengamatan adalah kegiatan yang dilakukan bersamaan dengan pelaksanaan tindakan dengan melihat langsung kegiatan proses pembelajaran. 
Berdasarkan pengamatan yang dilakukan selama proses pembelajaran berlangsung pada siklus kedua diperoleh hasil sebagai berikut:

(a) Siswa mulai aktif dan tidak malu-malu lagi untuk bertanya

(b) siswa sudah berani mengemukakan pendapatnya sendiri.

Ketika dilakukan evaluasi peningkatan minat belajar siswa pada pelajaran Pendidikan Agama Islam mengalami peningkatan yang baik.

4). Refleksi

Refleksi merupakan tahapan untuk mengkaji dan memproses data yang didapat saat dilakukan pengamatan. Adapun keberhasilan yang diperoleh pada siklus II adalah sebagai berikut:

(a) Aktivitas peserta didik dalam proses pembelajaran Pendidikan Agama Islam melalui penerapan metode diskusi menarik perhatian siswa hal ini disebabkan peneliti menggabungkan instrumen penelitian soal essay dan tanya jawab sehingga siswa berminat untuk mengikuti proses pembelajaran.

(b) Peneliti mampu membangun minat dan keaktifan belajar siswa dalam pembelajaran Pendidikan Agama Islam

(c) Peningkatan minat belajar siswa baik dengan proses pembelajaran yang sesuai dengan RPP yang telah dirancang peneliti.

\section{Penutup}

Penerapan metode diskusi yaitu melalui tiga tahapan. a). Tahap sebelum pertemuan dimana guru memilih topik diskusi dan memberikan penjelasan tentang topik yang akan didiskusikan. b). Tahap selama pertemuan yaitu guru mengelompokkan siswa menjadi 4 kelompok, tiap kelompok diberikan sub materi yang berbeda, guru dan siswa melaksanakan diskusi. c). 
Tahap setelah pertemuan yaitu mengevaluai kembali materi diskusi dan menyimpulkan pokok pembahasan.

Minat belajar siswa dapat dilihat dari hasil belajar siswa pada pembelajaran Pendidikan Agama Islam dengan menggunakan metode diskusi, sebab jika hasil belajar siswa tinggi maka minat belajarnya pun akan tinggi sebagaimana hasil penelitian ini. Adapun hasil belajar siswa pada siklus I yang mendapatkan nilai dalam kategori baik sekali sebanyak 7 siswa $(29,17 \%)$, sedangkan pada siklus II yang mendapatkan nilai dalam kategori baik sekali sebanyak 17 siswa (70,83\%). Artinya bahwa minat belajar siswa terhadap pelajaran Pendidikan Agama Islam melalui penerapan metode diskusi kelasX7 SMA Negeri 4 Palopo dari siklus I ke siklus II mengalami peningkatan yang baik.

\section{Daftar Pustaka}

Ahmadi. Psikologi Belajar. Jakarta: Rineka Cipta, 2004.

Departemen Pendidikan dan Kebudayaan, Kamus Besar Bahasa Indonesia. Cet. III; Jakarta: Balai Pustaka, 1994.

Faturrohman, Pupuh \& M. Sobry Sutikno, Strategi Belajar Mengajar. Bandung, PT. Refika Aditama, 2010.

Muliawan, Jasa Ungguh. 45 Model Pembelajaran Spektakuler. Cet. I Ar Ruzz Media, 2016.

Slameto, Belajar dan Faktor-faktor yang Mempengaruhinya. Cet: IV Jakarta: PT. Rineka Cipta, 2003

Sriyono, dkk. Teknik Belajar Mengajar dalam CBSA. Jakarta: PT. Rineka Cipta 1992.

Suyanto dan Asep Jihad, Menjadi Guru Profesional stragtegi Meningkatkan Kualifikasi dan Kualitas Guru di Era Global. Erlangga Groub, 2013. 